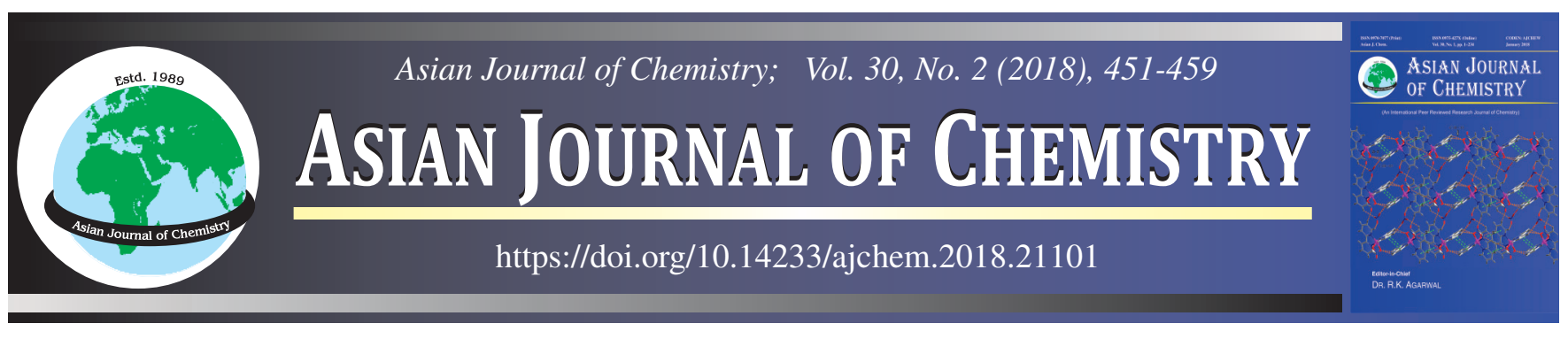

\title{
Synthesis, Photophysical and Electrochemical Studies on Peripherally Ruthenated Tetraphenylporphyrin
}

\section{S. TAMiJSELVY}

School of Basic Sciences, Department of Chemistry, Vels Institute of Science, Technology \& Advanced Studies, Chennai-600 117, India Corresponding author: E-mail: tamijselvy@gmail.com

\begin{abstract}
Ruthenium(II) complexes of 5-(4-hydroxyphenyl)-10,15,20-tris-(4-methylphenyl)porphyrin and 5,10,15,20-tetrakis(4-hydroxyphenyl)porphyrin have been synthesized in basic medium and spectroscopically characterized. The complexes show broad bands in the visible region due to overlap of porphyrin transitions with the metal-to-ligand charge transfer (MLCT) transitions arising from cis- $\left.\mathrm{Ru}_{(\mathrm{bipy}}\right)_{2} \mathrm{Cl}_{2}$.

${ }^{1} \mathrm{H}$ NMR indicates $\pi$-electron interactions between the porphyrin ring and bipyridyl rings. The complexes are emissive both at room temperature and at $77 \mathrm{~K}$ with two independent emissions at $77 \mathrm{~K}$, one from the excited state of the porphyrin moiety at 650 and $720 \mathrm{~nm}$ and the other from the excited state of the ruthenium moiety at $700 \mathrm{~nm}$. No excited state intramolecular energy transfer reactions have been detected. However the quantum yield of the complexes is reduced due to heavy atom effect. Time resolved fluorescence decay analyses show dual life time at 1.5 and $7.7 \mathrm{~ns}$ in dichloromethane. The shorter life time is assigned to singlet-excited state of ruthenium and longer life time to porphyrin singlet excited state. Electrochemical analysis of these species in dichloromethane exhibits three anodic peaks at around $0.68,0.98$ and $1.42 \mathrm{~V}$ versus $\mathrm{SCE}$, analogous to the $\mathrm{Ru}^{3+/ 2+}$ couple and two successive one-electron oxidation processes on the porphyrin ring, respectively. On the other hand, cathodic potentials at around $-0.8,-1.4$ and $-1.54 \mathrm{~V}$ versus SCE, with first two peaks corresponding to two successive reduction taking place at the porphyrin ring and the third peak corresponding to reduction of bipyridyl unit. All spectroscopic studies reveal perturbation on the electronic levels of both porphyrin ring and ruthenium chromophore.
\end{abstract}

Keywords: Ruthenated, Porphyrin, Perturbation, Emission, Life time, Electrochemistry.

\section{INTRODUCTION}

Supramolecular chemistry, also known as "chemistry outside a molecule" is the heart of the development of chemistry of complex systems, molecular devices, ensembles and nanochemistry [1]. This is the chemistry where molecules are able to self-organize, self-assemble and self-control into systems and the components are often analogues to biological molecules. Metalloporphyrins and metallophthalocyanines are remarkable precursors in supramolecular chemistry and the rapid development of this chemistry led to assemblies possessing various architectures and properties (photo-, electro- and catalytic properties and others). Metalloporphyrins are one of the foundations on which the existence of life is based and major biochemical, enzymatic and photochemical functions depend on the special properties of a tetrapyrrolic macrocycle. However, metalloporphyrins are the only molecules as key elements that require assembly with other elements to form the supramolecular structure.

In natural systems, polypeptides define a given structural organization and hold all the moieties together. Such complex natural devices are not accessible by direct chemical synthesis so far, but their modeling, using simplified designs, has been actively exploited during the last decades. The rapid development of this new area of chemistry has promoted the understanding of the concepts of design and strategies of selfassembly of structures based on intermolecular interactions to result in natural and synthetic supramolecular complexes of metalloporphyrins. Synthetic metalloporphyrin complexes are often used as analogues of natural systems found in photosynthesis, oxygen carriers and catalysts $[2,3]$. These studies lead to the discovery of new applications in photodynamic therapy, information storage devices or photoelectrical devices that transform energy in both directions (photocells and lightemitting diodes) [4-6]. An application of increasing importance is the use of metalloporphyrins as receptors, exploiting their ability to selectively form complexes which can sharply change the spectral properties [7,8]. Macrocyclic porphyrin oligomers with cavities suitable for selective molecular recognition [9] and homogeneous catalysis [10] are also known. Most examples deal with porphyrins bearing meso-pyridyl groups, since the easy coordination ability of pyridine group 
allows large assemblies to be built. In recent times, the physicochemical properties of tetraruthenated metalloporphyrins have been investigated. Its synthesis and photophysical properties of zinc porphyrin and cobalt porphyrin [11-14], electrocatalytic [15-19], analytical application [20] and DNA interactions $[21,22]$ have been studied. The above mentioned results of peripherally ruthenated porphyrins have one common aspect, i.e., all compounds are based on meso-tetrapyridyl metalloporphyrins. However, three features have not been studied so far, namely, (i) how ruthenium ion can coordinate to other donor atoms at the meso position, e.g. hydroxy group and what effect it will show on the photophysics, (ii) what will be the effect if ruthenium is coordinated at the periphery of a free base porphyrin instead of a metalloporphyrin, (iii) the above mentioned peripheral compounds indicates that intramolecular energy transfer takes place from ${ }^{3} \mathrm{MLCT} *$ of ruthenium(II) to ${ }^{3} \mathrm{MP}^{*}[23,24]$. However no one has studied whether a reverse energy transfer is possible or not by lifting the energy of porphyrin either equal to or above the energy levels of ruthenium chromophore.

Keeping these skin texture, we synthesized meso ruthenated porphyrins, namely, symmetrically substituted tetraruthenium porphyrin from meso-5,10,15,20-tetrakis-(4-hydroxyphenyl)porphyrin and mono substituted ruthenium porphyrin from meso-5-(4-hydroxyphenyl)-10,15,20-tris-(4-methylphenyl)porphyrin. This type of molecule is particularly interesting, since it coalesce the characteristics and properties of porphyrin and ruthenium bipyridyl species, allowing the preparation of new macromolecular complex. It is to be noted that synthesis of these complexes using hydroxy as one of the coordinating ligand from the porphyrin makes the ruthenium chromophore moiety greatly affected by the porphyrin unit due to greater flexibility of the bent $\mathrm{Ru}-\mathrm{O}$ bond with respect to the meso phenyl group. This makes the ruthenium chromophore disposed spatially closer towards the porphyrin ring unlike that of Anson [1619], Toma and Araki [21], etc. Herein we report the synthesis, spectroscopic and electrochemical properties of the complexes. From the literature survey, we believe that this is the first report on singlet life time data of such type of peripherally ruthenated free base porphyrin monomers and also our observation of dual emission is hitherto unknown in these types of complexes.

\section{EXPERIMENTAL}

4-Methoxy benzaldehyde, pyrrole and propionic acid were bought from SD fine, India, were used after purification [25]. All the solvents used were analytical grade and were dried further whenever required. The precursor ligands 5,10,15,20tetrakis-(4-methoxyphenyl)porphyrin (A) [26], 5-(4-methoxyphenyl)-10,15,20-tris-(4-methylphenyl)porphyrin (B) [27], 5,10,15,20-tetrakis-(4-hydroxyphenyl)porphyrin (I) [28], 5(4-hydroxyphenyl)-10,15,20-tris-(4-methylphenyl)porphyrin (II) [29] and cis-dichloro-bis-bipyridylruthenium(II) (III) [30] were synthesized as described in the literature. These ligands have been characterized from ${ }^{1} \mathrm{H}$ NMR technique and the data are tabulated in Table-1.

5,10,15,20-Tetrakis (4-(hydroxo-chloro-bis-bipyridylruthenium(II))phenoxo) porphyrin [IV]: Synthesis of the complex IV involves two steps. Firstly, the precursor, I (0.34 $\mathrm{g}, 0.5 \mathrm{mmol}$ ) was refluxed with anhydrous potassium carbonate $(0.3 \mathrm{~g}, 2.2 \mathrm{mmol})$ in $75 \mathrm{~mL}$ of dry dimethyl formamide under nitrogen atmosphere for $24 \mathrm{~h}$. Secondly, the metal precursor, III (1.17 g, $2.2 \mathrm{~mol})$ was added under nitrogen atmosphere and refluxed for further $24 \mathrm{~h}$. The completion of reaction was monitored using TLC. The $\mathrm{R}_{\mathrm{f}}$ value was found to be 0.5 in pure chloroform on an alumina coated plate. The volume of the resultant solution was reduced to one fourth under vacuum and then extracted with dichloromethane. The organic layer was washed with water, dried over anhydrous sodium sulfate and concentrated under reduced pressure. The residue was purified using column chromatography on basic alumina, initially with chloroform and followed by $2 \%$ methanol in chloroform as eluant to afford $0.150 \mathrm{~g}(11.5 \%)$ of IV. FAB-MS, $m / z$ : calculated for $\mathrm{C}_{124} \mathrm{H}_{106} \mathrm{~N}_{20} \mathrm{O}_{12} \mathrm{Ru}_{4} \mathrm{Cl}_{4}$ : 2612; found: 2010, [M$\left.\mathrm{C}_{20} \mathrm{H}_{38} \mathrm{~N}_{4} \mathrm{O}_{9} \mathrm{RuCl}\right]^{+}$. Anal. Calcd for $\mathrm{C}_{124} \mathrm{H}_{106} \mathrm{~N}_{20} \mathrm{O}_{12} \mathrm{Ru}_{4} \mathrm{Cl}_{4}$ : C, 60.3; H, 3.7; N, $11.4 \%$; found: C, 60.0; H, 3.4, N, $11.8 \%$.

[5((4)(Hydroxo-chloro-bis-bipyridyl-ruthenium(II))phenoxo)-10,15,20-tri(4-methylphenyl)]porphyrin [V]: Compound $\mathbf{V}$ was prepared by following a similar procedure described for IV except that II (0.35 g, $0.5 \mathrm{mmol})$ was used instead of $\mathbf{I}$. Ratios of anhydrous potassium carbonate $(0.085$ $\mathrm{g}, 0.6 \mathrm{mmol})$ and III $(0.312 \mathrm{~g}, 0.6 \mathrm{mmol})$ were reduced to one fourth instead of the ratio mentioned in IV. The $\mathrm{R}_{\mathrm{f}}$ value on an alumina-coated plate was found to be 0.45 in 7:3 hexane and chloroform mixture. Pure $\mathbf{V}$ was obtained by column chromatography on basic alumina using hexane and chloroform as eluant in the ratio of 4:6. Yield $0.184 \mathrm{~g}(41.8 \%)$. FAB-MS, $m / z$ : calculated for $\mathrm{C}_{67} \mathrm{H}_{53} \mathrm{~N}_{8} \mathrm{O}_{3} \mathrm{RuCl}$ : 1153; found: 881, [M- $\left.\mathrm{C}_{15} \mathrm{H}_{18} \mathrm{~N}_{3} \mathrm{O}_{2}\right]^{+}$. Anal. calcd. for $\mathrm{C}_{67} \mathrm{H}_{53} \mathrm{~N}_{8} \mathrm{O}_{3} \mathrm{RuCl}$ : C, 72.0; H, 4.3; N, $10.0 \%$; found: C, 71.8; H, 4.1; N, $9.7 \%$.

Spectroscopic studies: Electronic absorption spectra were obtained with Ocean optics optical fiber $(400 \mu \mathrm{m})$ spectrophotometer SD1000 using $1 \mathrm{~cm}$ quartz cell in dichloromethane. IR spectra were recorded on ABB Bomem MB 104 spectrometer using $\mathrm{KBr}$ disks. Elemental (C, $\mathrm{H}$ and $\mathrm{N}$ ) analysis was performed with Heraus Rapid analyzer. ${ }^{1} \mathrm{H}$ NMR spectra were recorded on AMX-400 NMR spectrometer in $\mathrm{CDCl}_{3} / \mathrm{DMSO}$, using TMS as the internal standard. FAB mass spectra were recorded on a JEOL SX 102/DA-6000 mass spectrometer/Data system using Argon/Xenon $(6 \mathrm{kV}, 10 \mathrm{~mA})$ as the FAB gas.

Fluorescence studies: Fluorescence spectra of the ligands and their ruthenium(II) complexes were recorded in dichloromethane, acetone, ethanol, methanol and acetonitrile using Hitachi F4500 spectrofluorimeter fitted with R928 photomultiplier tube employing right angle detection mode. Fluorescence quantum yields $\left(\phi_{\mathrm{fl}}\right)$ were measured by optically dilute method [31] using meso-5,10,15,20-tetraphenyl porphyin as standard $\left(\phi_{\mathrm{fl}}=0.13\right.$ in benzene) [32]. Spectra at $77 \mathrm{~K}$ were obtained by cooling the samples in a quartz Dewar flask filled with liquid nitrogen. The fluorescence decay measurements of were carried out using the time correlated single photon counting technique (TCSPC) with micro channel plate photomultiplier tube (MCPPMT) as detector and picoseconds laser as the excitation source. The measured fluorescence decay data were analyzed for various fluorescence kinetic parameters (life time, amplitudes etc.) using the software provided by IBH (DAS-6) which is based on reconvolution technique using iterative non-linear 
TABLE-1

${ }^{1} \mathrm{H}$ NMR (300/400 MHz) INFORMATION OF LIGANDS AND COMPLEXES WITH TMS AS INTERNAL REFERENCE

\begin{tabular}{|c|c|c|c|c|}
\hline \multirow{2}{*}{ Complex } & \multicolumn{3}{|c|}{ Porphyrins } & \multirow{2}{*}{ 2,2'-bipyridyl protons (ppm) } \\
\hline & $\mathrm{N}-\mathrm{H}$ protons $(\mathrm{ppm})$ & $\beta$-Protons (ppm) & meso aryl groups' protons (ppm) & \\
\hline I $\left(\right.$ DMSO- $\left.d_{6}\right)$ & $-2.88,2 \mathrm{H}$ & $8.86,8 \mathrm{H}$ & $\begin{array}{l}\mathrm{H}_{2,6}=8.0\left(8 \mathrm{H}, J_{2,3}=8.4 \mathrm{~Hz}\right) \\
\mathrm{H}_{3,5}=7.21\left(8 \mathrm{H}, J_{2,3}=8.4 \mathrm{~Hz}\right) \\
\mathrm{H}_{4-\mathrm{OH}}=9.94,4 \mathrm{H}\end{array}$ & \\
\hline II $\left(\mathrm{CDCl}_{3}\right)$ & $-2.77,2 \mathrm{H}$ & $8.85,8 \mathrm{H}$ & $\begin{array}{l}\mathrm{H}_{2,6,2^{\prime}, 6^{\prime}}=8.10-8.04,8 \mathrm{H} \\
\mathrm{H}_{3,5}=7.19\left(2 \mathrm{H}, J_{2,3}=8.4 \mathrm{~Hz}\right) \\
\mathrm{H}_{3^{\prime}, 5^{\prime}}=7.55\left(6 \mathrm{H}, J_{2^{\prime}, 3^{\prime}}=8.1 \mathrm{~Hz}\right) \\
\mathrm{H}_{4-\mathrm{OH}}=9.94,1 \mathrm{H} \\
\mathrm{H}_{4^{\prime}-\mathrm{CH} 3}=2.7,9 \mathrm{H}\end{array}$ & \\
\hline III $\left(\mathrm{CDCl}_{3}\right)$ & & & & $\begin{array}{l}\mathrm{H}_{\mathrm{A} 6 \mathrm{~B} 6}=8.17,2 \mathrm{H} \mathrm{H}_{\mathrm{A} 6^{\prime} \mathrm{B} 6}=7.6,2 \mathrm{H} \\
\mathrm{H}_{\mathrm{A} B \mathrm{~B} 5}=7.92-7.85,2 \mathrm{H} \\
\mathrm{H}_{\mathrm{A} 5^{5} \mathrm{~B} 5}=7.51-7.45,2 \mathrm{H} \\
\mathrm{H}_{\mathrm{A} 4 \mathrm{~B} 4}=7.62-7.58,2 \mathrm{H} \\
\mathrm{H}_{\mathrm{A}^{4} \mathrm{~B} 4}=7.31-7.23,2 \mathrm{H} \\
\mathrm{H}_{\mathrm{A}^{3} \mathrm{~B} 3}=8.13,2 \mathrm{H} \\
\mathrm{H}_{\mathrm{A} 3^{3} 3^{3}}=8.05,2 \mathrm{H} \\
\mathrm{H}_{2} \mathrm{O}=6.9-7.0,4 \mathrm{H}\end{array}$ \\
\hline IV $\left(\mathrm{CDCl}_{3}\right)$ & $1.26,2 \mathrm{H}$ & $7.79,8 \mathrm{H}$ & $\begin{array}{l}\mathrm{H}_{2,6}=8.18,\left(8 \mathrm{H}, J_{2,3}=4.5 \mathrm{~Hz}\right) \\
\mathrm{H}_{3,5}=6.75,\left(8 \mathrm{H}, J_{2,3}=4.5 \mathrm{~Hz}\right)\end{array}$ & $\begin{array}{l}\mathrm{H}_{\mathrm{A} 6 \mathrm{~B} 6}=8.65,(8 \mathrm{H}, J=8.1 \mathrm{~Hz}) \\
\mathrm{H}_{\mathrm{A} 3 \mathrm{~B} 3}=8.57,(8 \mathrm{H}, J=7.5 \mathrm{~Hz}) \\
\mathrm{H}_{\mathrm{B} 6}=8.39,(4 \mathrm{H}, J=8.1 \mathrm{~Hz}) \\
\mathrm{H}_{\mathrm{A} 4 \mathrm{~B} 4}=8.35-8.31,8 \mathrm{H} \\
\mathrm{H}_{\mathrm{B} 5} \& \mathrm{H}_{\mathrm{B} 4}=7.88-7.68,8 \mathrm{H} \\
\mathrm{H}_{\mathrm{A} 6}=7.65,(4 \mathrm{H}, J=5.4 \mathrm{~Hz}) \\
\mathrm{H}_{\mathrm{A} 3} \& \mathrm{H}_{\mathrm{A} 4}=7.24-7.13,8 \mathrm{H} \\
\mathrm{H}_{\mathrm{A} 5}=6.82-6.77,4 \mathrm{H} \\
\mathrm{H}_{\mathrm{B} 3}=7.5,4 \mathrm{H} \\
\mathrm{H}_{2} \mathrm{O}=7.1-7.0,16 \mathrm{H}\end{array}$ \\
\hline $\mathbf{V}\left(\mathrm{CDCl}_{3}\right)$ & $0.87,2 \mathrm{H}$ & $7.65-7.8,8 \mathrm{H}$ & $\begin{array}{l}\mathrm{H}_{2,6}=8.18,\left(2 \mathrm{H}, J_{2,3}=4.44 \mathrm{~Hz}\right) \\
\mathrm{H}_{3,5}=6.8,\left(2 \mathrm{H}, J_{2,3}=4.68 \mathrm{~Hz}\right) \\
\mathrm{H}_{2^{\prime}, 6^{\prime}}=8.0,\left(6 \mathrm{H}, J_{2^{\prime}, 3^{\prime}}=5.28 \mathrm{~Hz}\right) \\
\mathrm{H}_{3^{\prime}, 5^{\prime}}=7.5\left(6 \mathrm{H}, J_{2^{\prime}, 3^{\prime}}=5.48 \mathrm{~Hz}\right) \\
\mathrm{H}_{4^{\prime} \cdot \mathrm{CH} 3}=2.2,9 \mathrm{H}\end{array}$ & $\begin{array}{l}\mathrm{H}_{\mathrm{A} 6 \mathrm{~B} 6}=8.9,(2 \mathrm{H}, J=8.4 \mathrm{~Hz}) \\
\mathrm{H}_{\mathrm{A} 3 \mathrm{~B} 3}=8.82,(2 \mathrm{H}, J=7.92) \\
\mathrm{H}_{\mathrm{B} 6}=8.8,(1 \mathrm{H}, J=8.0 \mathrm{~Hz}) \\
\mathrm{H}_{\mathrm{A} 4 \mathrm{~B} 4}=8.39-8.42,2 \mathrm{H} \\
\mathrm{H}_{\mathrm{A} 5 \mathrm{~B} 5}=8.10-8.14,2 \mathrm{H} \\
\mathrm{H}_{\mathrm{B} 4^{\prime}} \& \mathrm{H}_{\mathrm{B} 5}=7.91-7.7,2 \mathrm{H} \\
\mathrm{H}_{\mathrm{A} 6}=7.64,(1 \mathrm{H}, J=5.4) \\
\mathrm{H}_{\mathrm{B} 3^{\prime}}=7.49-7.46,2 \mathrm{H} \\
\mathrm{H}_{\mathrm{A} 4^{\prime}} \& \mathrm{H}_{\mathrm{A}}=7.25-7.13,2 \mathrm{H} \\
\mathrm{H}_{\mathrm{A} 5}=6.89-6.78,1 \mathrm{H} \\
\mathrm{H}_{2} \mathrm{O}=7.1-7.0,4 \mathrm{H}\end{array}$ \\
\hline
\end{tabular}

least square methods. The reconvolution is preceded by the series of iterations until a Chi-Square is reduced. The quality of fit is normally identified by the reduced $\chi^{2}$, weighted residual and the autocorrelation function of the residuals. The fluorescence decay measurements were carried out using various solvents such as acetone, acetonitrile, methanol, ethanol and dichloromethane.

Electrochemistry: All electrochemical experiments were performed in Ecochemie AUTOLAB PGSTAT 12 using conventional three-electrode setup with saturated calomel electrode as reference, $2 \mathrm{~mm}$ diameter platinum disc as working and platinum rod as auxially electrodes. Generally all the cyclic voltammogram were performed with scan rate $50 \mathrm{mV} / \mathrm{s}$ in dichloromethane/acetonitrile solvent based on the solubility of the substance. For recording square wave voltammogram a constant frequency of $8 \mathrm{~Hz}$ with step potential of $4 \mathrm{mV}$ and pulse amplitude of $10 \mathrm{mV}$ was employed.

\section{RESULTS AND DISCUSSION}

Synthesis: Reactions 1 and 2 shows the synthetic strategy adopted for the synthesis of ruthenium complexes with 1:4 and 1:1 molar ratios of freebase porphyrin and $\mathrm{Ru}(\text { bipy })_{2} \mathrm{Cl}_{2}$.
The yield is found to be moderate. The complexes IV and $\mathbf{V}$ are freely soluble in dichloromethane and other low polarity solvents; unlike the free base porphyrin I/II and the solution of these complexes are found to be stable in the atmosphere. However, solvation of the chloro group is found to occur rapidly in polar solvents. The space-filling model suggests the possibility of atropisomers, arising out of the disposition of the bipyridyl ring with respect to porphyrin plane. However, we did not attempt to separate the atropisomers. We also believe that all the isomers would show similar spectral properties.

$$
\begin{gathered}
\left.\mathrm{H}_{2} \mathrm{THPP}+4 \text { cis - Ru(bipy }\right)_{2} \mathrm{Cl}_{2} \\
\stackrel{\mathrm{DMF} / \mathrm{K}_{2} \mathrm{CO}_{3}}{\longrightarrow} \mathrm{H}_{2} \mathrm{~T}\left(\mathrm{Ru}(\text { bipy })_{2} \mathrm{Cl}\right) \mathrm{PP} \\
\mathrm{H}_{2} \mathrm{TTHPP}+\text { cis }-\mathrm{Ru}(\text { bipy })_{2} \mathrm{Cl}_{2} \\
\stackrel{\mathrm{DMF} / \mathrm{K}_{2} \mathrm{CO}_{3}}{\longrightarrow} \mathrm{H}_{2} \mathrm{TT}\left(\mathrm{Ru}(\text { bipy })_{2} \mathrm{Cl}\right) \mathrm{PP}
\end{gathered}
$$

FAB mass analysis first reveals the presence of more than one ruthenium unit in the complex IV and one unit in $\mathbf{V}$. In complex IV, the adduct peak due to loss of [O-Ru(bipy $\left.)_{2} \mathrm{Cl}\right]^{-}$ fragment from the parent complex is detected as $[\mathrm{M}+6]^{+}$peak at 2010. This observation of $[\mathrm{M}+6]$ peak at 2010, strongly 
suggests the presence of at least three chlorine atoms and the assignment of loss of one ruthenium complex from IV is from the other spectral evidences. Probably, the molecular ion peak is so weak, that escaped notice [33].

Similarly, the FAB mass investigation of complex $\mathbf{V}$ also resulted only in adduct peak and no molecular ion peak is detected. The adduct peak due to loss of one of the 2,2'-bipyridyl and a pyridyl ring from $\left[\mathrm{Ru}(\text { bipy })_{2} \mathrm{Cl}\right]^{+}$segment is found at 881. Also loss of remaining pyridyl ring along with chlorine atom and ruthenium resulted in an adduct peak at 666 ion peak.

${ }^{1} \mathbf{H}$ NMR spectra: The ${ }^{1} \mathrm{H}$ NMR spectrum of I and II clearly reveals the resonances characteristic of all the protons in the compound and all the values are in line with the earlier studies [34]. cis-[Ru(bipy) $\left.{ }_{2} \mathrm{Cl}_{2}\right] \cdot 2 \mathrm{H}_{2} \mathrm{O}$ showed characteristic peaks corresponding to various protons in the range of 7 to $10 \mathrm{ppm}$ in $\mathrm{CDCl}_{3}$ solvent.
${ }^{1} \mathrm{H}$ NMR of $\mathbf{I V}$ and $\mathbf{V}$ in $\mathrm{CDCl}_{3}$ is reproduced in Figs. 1 and 2, respectively and the resonance positions of various protons are given in Table-1. The notable features of the spectrums are (i) shift in the resonance positions of pyrrole protons due to variation in the number of ruthenium moiety coordinated. Thus an upfield shift in the resonances of $\beta$-pyrrole protons from 8.8 to $8 \mathrm{ppm}$ in $\mathbf{I V}$ and to $7.7 \mathrm{ppm}$ in $\mathbf{V}$. Also the $\mathrm{N}-\mathrm{H}$ protons shifts from -2.8 to $1.26 \mathrm{ppm}$ in IV and to $0.87 \mathrm{ppm}$ in V. These change in the resonance positions clearly indicates interaction of the electronic cloud of bipyridyl present in the $\left[\mathrm{Ru} \text { (bipy) }{ }_{2} \mathrm{Cl}\right]^{+}$fragment with the $\pi$-cloud of porphyrin. This also suggest that one of the bipyridyl rings coordinated to ruthenium may be perpendicular to porphyrin ring, so that the ring current of the pyridyl ring is parallel but opposite to the direction of porphyrin ring current. (ii) The meso-phenyl protons $\left(\mathrm{H}_{3,5}\right)$ also shows an upfield shift due to the increased

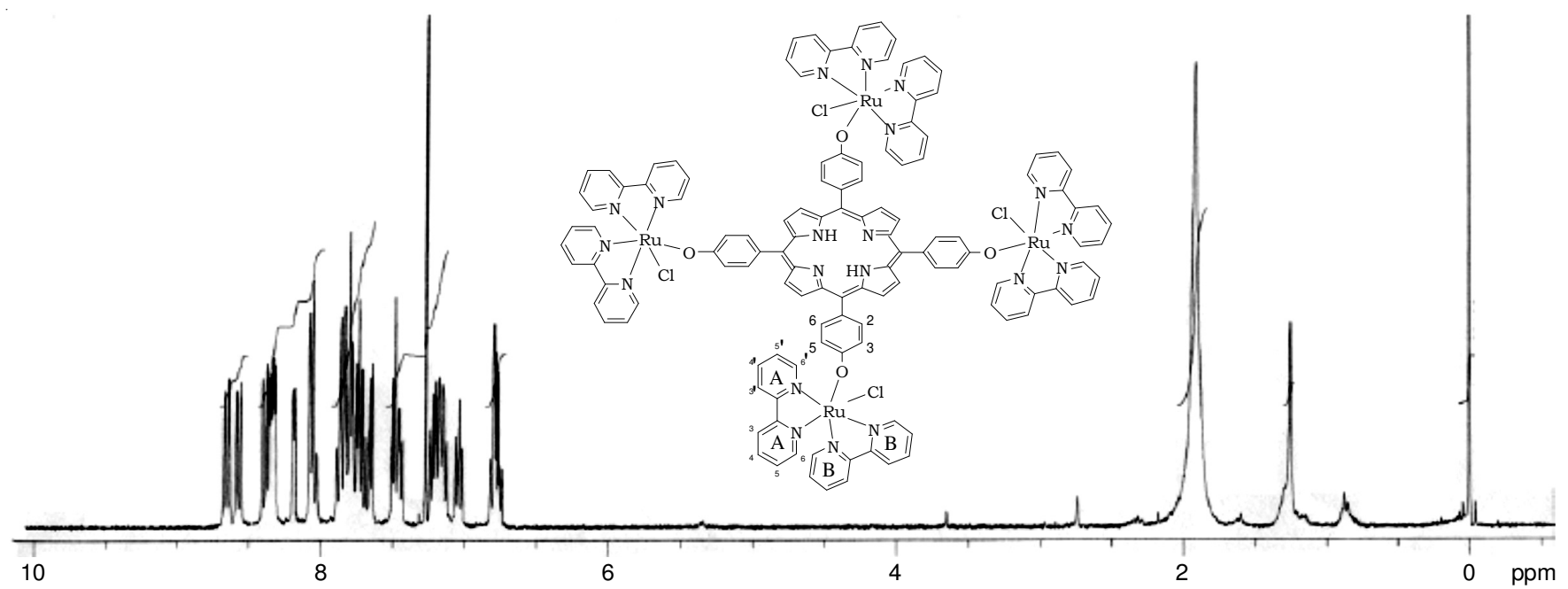

Fig. $1 .{ }^{1} \mathrm{H}$ NMR $\left(300 \mathrm{MHz}, \mathrm{CDCl}_{3}\right)$ spectrum of IV

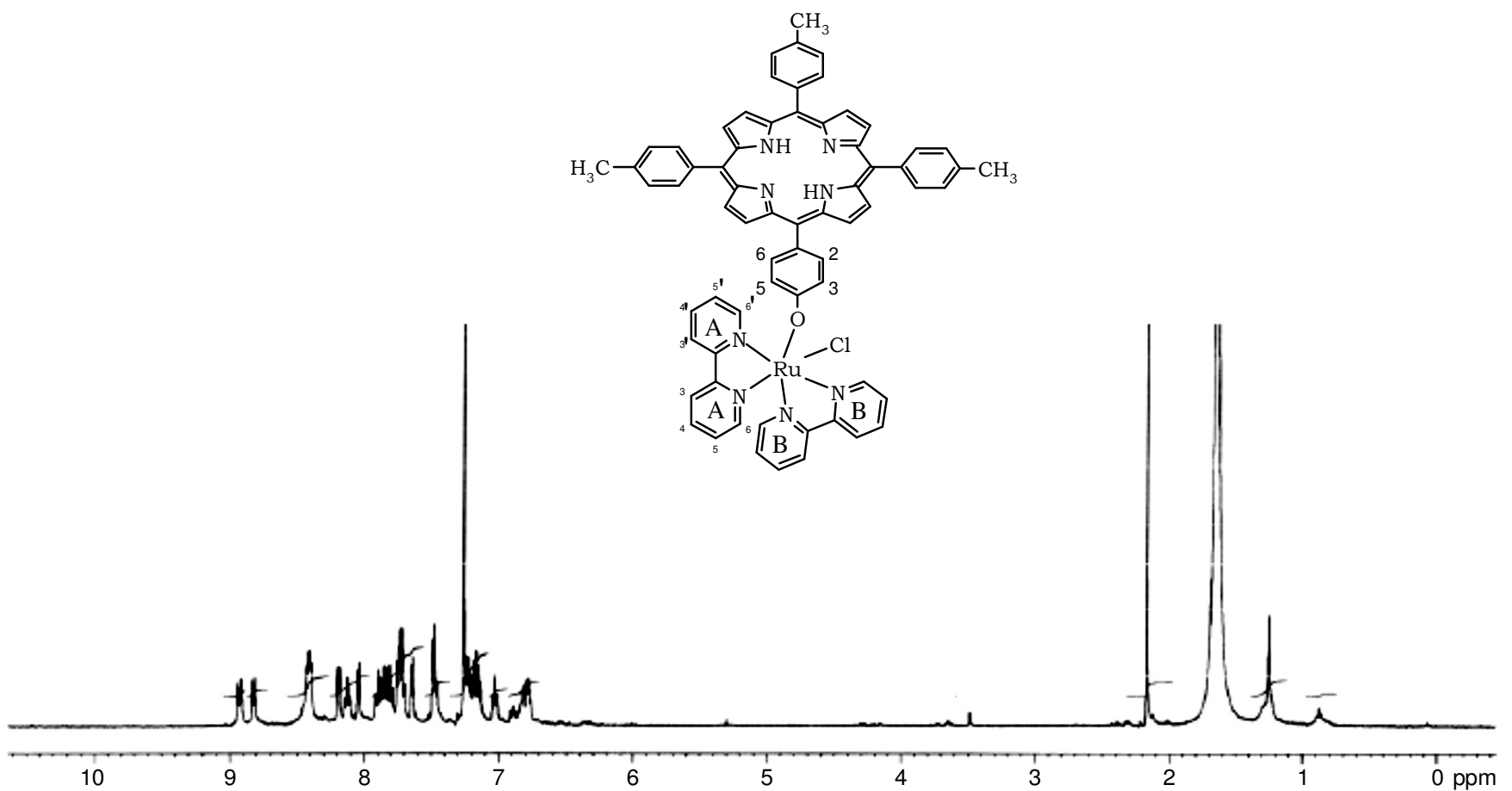

Fig. 2. ${ }^{1} \mathrm{H} \mathrm{NMR}\left(400 \mathrm{MHz}, \mathrm{CDCl}_{3}\right)$ spectrum of $\mathbf{V}$ 
electron density at 3 and 5 positions, arising as a result of ruthenium complex coordinated at the 4 position of the phenyl ring which facilitate back donation to the phenoxo group [35]. This is further confirmed in the electrochemical behaviour (see later). (iii) Some of the bipyridyl proton is shifted to upfield and some of them to downfield in comparison with the precursor III. This is believed to occur due to shielding and deshielding of these bipyridyl protons by the porphyrin $\pi$-cloud. Among the upfield shifted protons of the two-pyridyl rings of each bipyridyl show small difference in resonance positions. These variations arise due to the presence of two different electronegative atoms, oxygen and chlorine trans to two bipyridyl rings. The pyridyl protons, which are trans to oxygen atom, are more downfield shifted in comparison with those trans to chloride ion. The shifts in the resonance positions of the various pyridyl protons clearly justify the assumption that one of the bipyridyl rings is perpendicular to the porphyrin ring. The peaks around 7.1 to 7.0 appear from coordinated water [36]. This is further confirmed through $\mathrm{D}_{2} \mathrm{O}$ exchange (takes about $90 \mathrm{~min}$ for complete disappearance of the peak in $\mathrm{CDCl}_{3}$. Also the peak disappears in DMSO- $d_{6}$ due to DMSO coordination.

Absorption spectra: The de-convoluted absorption spectrum of $\mathbf{I V}$ and $\mathbf{V}$ in dichloromethane is shown in Fig. 3. The wavelengths of the absorption bands of all the complexes investigated are shown Table-2. The absorption spectrum of the complex IV and $\mathbf{V}$ shows broadened features both in Soret and $\mathrm{Q}$ band regions of porphyrins, due to overlap of absorption characteristic of a porphyrin and cis- $\mathrm{Ru}$ (bipy) ${ }_{2} \mathrm{Cl}_{2}$ units. The smeared peaks have been de-convoluted and the absorption spectra of the complexes, IV or $\mathbf{V}$, are dominated by strong ligand-centered $\pi-\pi^{*}$ transitions at around 290 and $350 \mathrm{~nm}$ on cis- $\mathrm{Ru}$ (bipy) ${ }_{2} \mathrm{Cl}_{2}$. The extinction coefficients of these transitions, $\pi-\pi^{*}$, in IV are found to be four times and are equal to in $\mathbf{V}$ than in $c i s-\mathrm{Ru}$ (bipy) ${ }_{2} \mathrm{Cl}_{2}$. The absorption bands arising from ruthenium fragment in the complexes $\mathbf{I V}$ and $\mathbf{V}$ are found to show a blue shift in comparison to $c i s-\mathrm{Ru}(\text { bipy })_{2} \mathrm{Cl}_{2}$. This indicates that there is increase in energy of the LUMO of
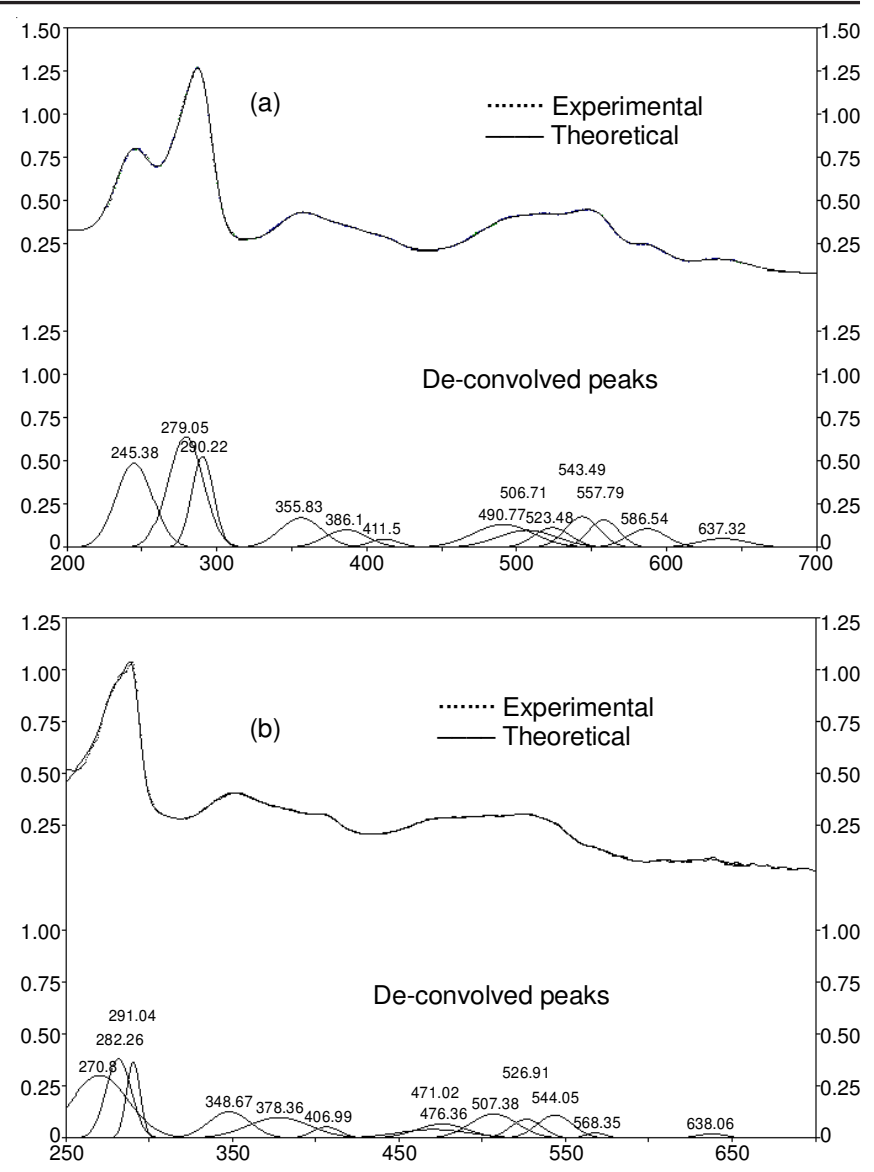

Fig. 3. Electronic absorption spectra of (a) 5,10,15,20-tetrakis((4(hydroxochloro-bis-bipyridyl-ruthenium(II))phenyl)porphyrin; (b) 5 ((4(hydroxo-chloro-bis-bipyridyl-ruthenium(II))phenyl), 10,15,20tri(tolyl)porphyrin in $\mathrm{CH}_{2} \mathrm{Cl}_{2}$ at $300 \mathrm{~K}$

ruthenium fragment causing MLCT bands to occur at higher energies.

Emission spectra: Room temperature fluorescence study on ruthenated porphyrins, namely, IV and $\mathbf{V}$, in solvents such as dichloromethane, acetonitrile, methanol, ethanol and acetone

TABLE-2

ELECTRONIC AND FLUORESCENCE, STEADY STATE AND LIFETIME, DATA OF FREE BASE PORPHYRIN, RUTHENIUM CHROMOPHORE AND meso MONO AND meso TETRA RUTHENATED PORPHYRIN COMPLEXES

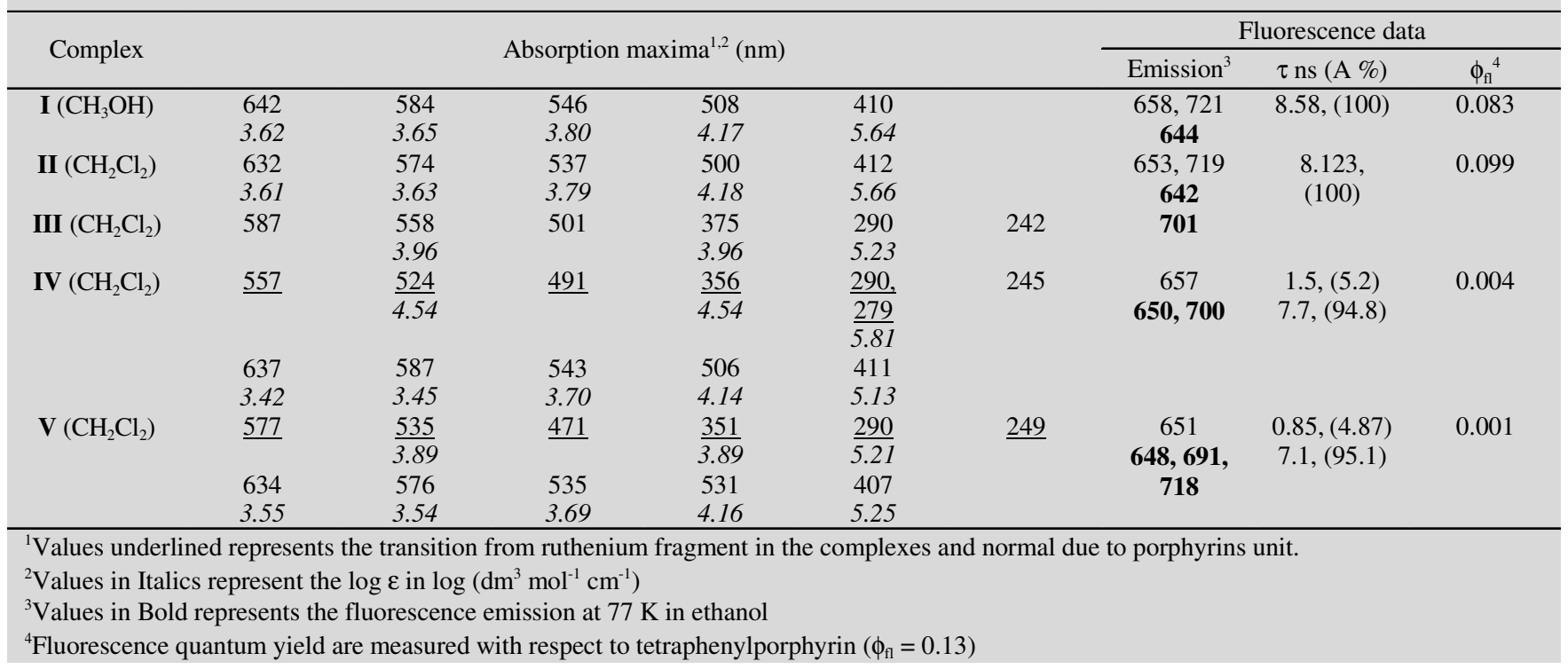


resulted in two fluorescence emission peaks at 650 and 720 $\mathrm{nm}$ when excited at $420 \mathrm{~nm}$, similar to that of the parent free base porphyrin. However, the normalized intensity is found to be low in comparison with that of I/II, which must arise from the effect of $\left[\mathrm{Ru}(\text { bipy })_{2} \mathrm{Cl}\right]^{+}$coordination. The quantum yields in $\mathbf{I V}$ and $\mathbf{V}$ are found to decrease drastically in comparison with the free base porphyrins. Thus the quantum yield of IV in dichloromethane is 0.004 while that of $\mathbf{V}$ is 0.001 . The difference in the values of quantum yield between $\mathbf{I V}$ and $\mathbf{V}$ reflects the variation in the number of ruthenium coordinated at the terminal. Thus to summarize, the quantum yield of IV/V in various solvents is decreased to about ten times than the free base porphyrins. Even though we observe some trend in the quantum yield on the solvent polarity we cannot give much emphasis to the trend, as the quantum yields are quite low. Since no definite solvent polarity dependence can be established in the spectral pattern, the decrease in the quantum yield is more likely due to heavy atom induced spin orbital coupling instead of any sort of intramolecular charge transfer process [36]. The fluorescence excitation spectrum from these two emission peaks resulted in two types of patterns one corresponding to the absorption spectrum of free base porphyrin $\left(\lambda_{\mathrm{em}}=650\right.$ $\mathrm{nm})$ and the other with broadened Q-bands $\left(\lambda_{\mathrm{em}}=720 \mathrm{~nm}\right)$.

The fluorescence emission spectrum of $\mathbf{I V}$ at $77 \mathrm{~K}$ in ethanol results in two well-defined emission bands at around 650 and $700 \mathrm{~nm}$ when excited at $420 \mathrm{~nm}$ (Fig. 4). But, the fluorescence emission spectrum of $\mathbf{V}$ at $77 \mathrm{~K}$ for the excitation at $420 \mathrm{~nm}$ results in an emission peaks similar to the room temperature fluorescence emissions but with a prominent shoulder like pattern at around $700 \mathrm{~nm}$. The intensity variation between IV and $\mathbf{V}$ is due to the difference in the number of ruthenium chromophores. Interestingly, the fluorescence excitation spectra at these emissions are found to be different. The fluorescence excitation spectrum from $650 \mathrm{~nm}$ emission resembles that of ground state absorption spectrum of the free base porphyrin, whereas, the fluorescence excitation spectrum of $700 \mathrm{~nm}$ emission results in an spectrum that resembles the room temperature absorption spectrum and fluorescence excitation spectrum (at $77 \mathrm{~K}$ ) of cis-[Ru(bipy) $\left.{ }_{2} \mathrm{Cl}_{2}\right]$. Excitation at $380 \mathrm{~nm}$ (absorption band of $c i s$ - $\left[\mathrm{Ru}(\text { bipy })_{2} \mathrm{Cl}_{2}\right]$ ) resulted in only one emission band

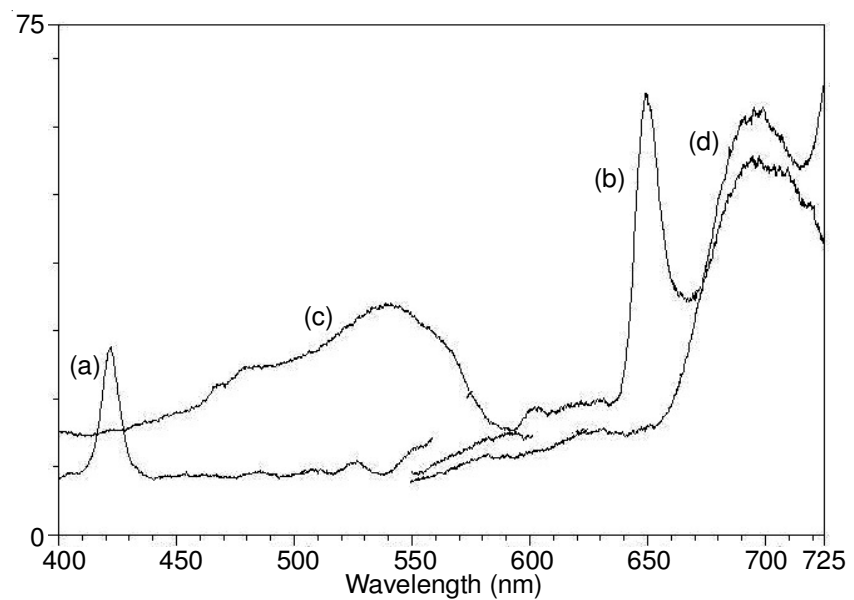

Fig. 4. Fluorescence (a) excitation spectrum of IV $\left(\lambda_{\mathrm{em}}=650 \mathrm{~nm}\right)$; (b) emission spectrum of IV $\left(\lambda_{\mathrm{ex}}=420 \mathrm{~nm}\right)$; (c) excitation spectrum of IV $\left(\lambda_{\mathrm{em}}=700 \mathrm{~nm}\right)$ and $(\mathrm{d})$ emission spectrum of IV $\left(\lambda_{\mathrm{ex}}=380 \mathrm{~nm}\right)$ in ethanol at $77 \mathrm{~K}$ at around $700 \mathrm{~nm}$ and no emission corresponding to porphyrin is observed for $\mathbf{I V}$, however, in $\mathbf{V}$ we could observe both emissions, 650 and $700 \mathrm{~nm}$, of equal intensities. This intensity discrepancy arises due to lower molar absorptivity of ruthenium chromophore in $\mathbf{V}$ at $380 \mathrm{~nm}$ as compared to $\mathbf{I V}$ at the same wavelength. Also the excitation spectrum of free base porphyrin, I, at $700 \mathrm{~nm}$ does not differ from that of $650 \mathrm{~nm}$ emission. Since other spectral data rules out the presence of unreacted cis-[Ru(bipy) $\left.{ }_{2} \mathrm{Cl}_{2}\right]$ as impurity, it is clear that the $700 \mathrm{~nm}$ emission originates from the excited state of ruthenium group. Excitation at other wavelengths corresponding to $\left[\mathrm{Ru}(\text { bipy })_{2} \mathrm{Cl}\right]^{+}$ group show similar results. All these results suggest that the two emissions are independent of each other suggesting that $\left.[\mathrm{Ru} \text { (bipy })_{2} \mathrm{Cl}\right]^{+}$units do not show any electronic interactions with porphyrin ring. This is quite contrast to the results observed by Araki and Toma [24], where a energy transfer from ${ }^{3} \mathrm{MLCT}^{*}$ of $\mathrm{Ru}$ (II) to ${ }^{3} \mathrm{ZnP} *$ has been observed.

The observation of two different emission properties made us to estimate fluorescence life time measurements through single photon-counting technique. The fluorescence decay of I and II in acetonitrile shows single exponential decay and the life times are found to be 8.58 and $8.12 \mathrm{~ns}$, respectively. The observed results are in agreement with earlier results [37]. The fluorescence decay of IV (Fig. 5e) and V (Fig. 5f) in dichloromethane is found to fit to a bi-exponential decay with life times at $1.5,7.7 \mathrm{~ns}$ and $0.85,7.1 \mathrm{~ns}$ with corresponding amplitudes of 5 and 95 , respectively. Since all spectroscopic investigation excludes the presence of any impurity, the two life times must originate from the excited states of the complexes.

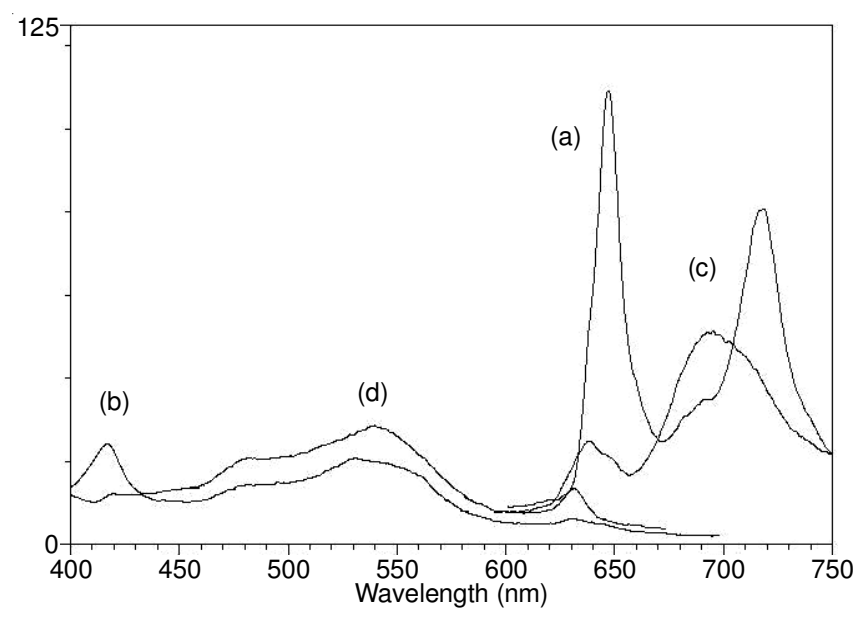

Fig. 5. Fluorescence (a) emission spectrum of $\mathbf{V}\left(\lambda_{\text {ex }}=420 \mathrm{~nm}\right)$; (b) excitation spectrum of $\mathbf{V}\left(\lambda_{\text {em }}=650 \mathrm{~nm}\right)$; (c) emission spectrum of $\mathbf{V}\left(\lambda_{\mathrm{ex}}=380 \mathrm{~nm}\right)$ and $(\mathrm{d})$ excitation spectrum of $\mathbf{V}\left(\lambda_{\mathrm{em}}=700 \mathrm{~nm}\right)$ in ethanol at $77 \mathrm{~K}$

In addition, bi-exponential decay does not get altered by external addition of $c i$ s-[Ru(bipy $\left.)_{2} \mathrm{Cl}_{2}\right]$. Similar bi-exponential decay is also observed for the emission at $700 \mathrm{~nm}$ and at 720 $\mathrm{nm}$. However, $700 \mathrm{~nm}$ emission, results in weak emission counts (about $20 \%$ ), but shows an increase in the amplitude of the shorter life time without any change in the life time value. This suggests that the shorter life time component has more contribution to the emission at $700 \mathrm{~nm}$. The $720 \mathrm{~nm}$ emission characteristic is found to be similar to that of $650 \mathrm{~nm}$ emission. In line with the observation of steady state fluorescence emission 


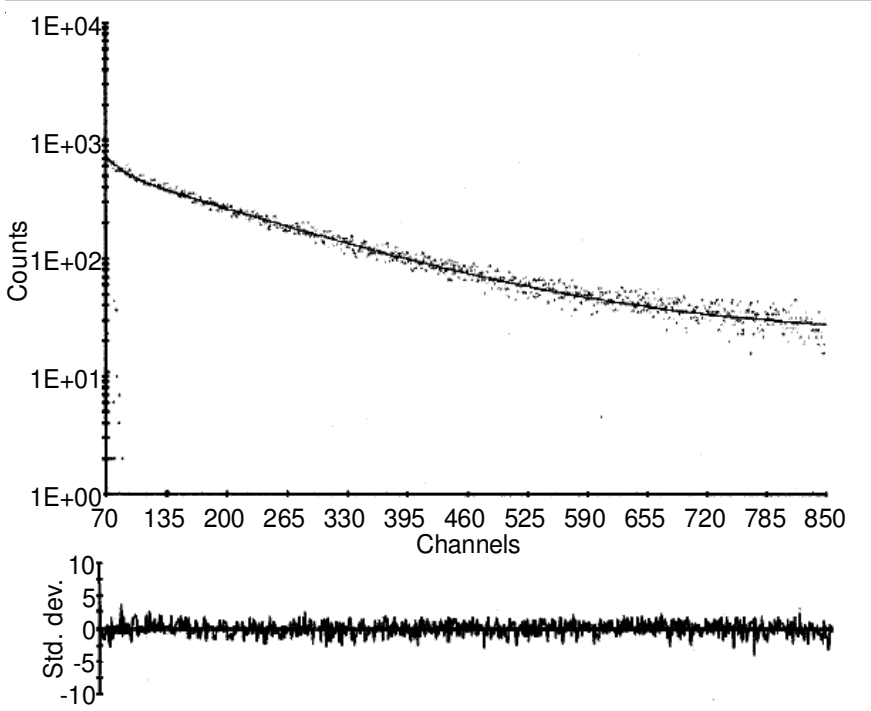

Fig. 5e. Fluorescence decay profile of IV in dichloromethane. The solid line represents best fit to $\mathrm{I}(\mathrm{t})=\mathrm{A}_{1} \exp ^{-1 / \tau_{1}}+\mathrm{A}_{2} \exp ^{-1 / \tau_{2}} \cdot \lambda_{\text {excitation }}=400$ $\mathrm{nm} \& \lambda_{\text {emission }}=650 \mathrm{~nm} . \tau_{1}=1.5 \mathrm{~ns}(5.2 \%) ; \tau_{2}=7.7 \mathrm{~ns}(94.8 \%)$
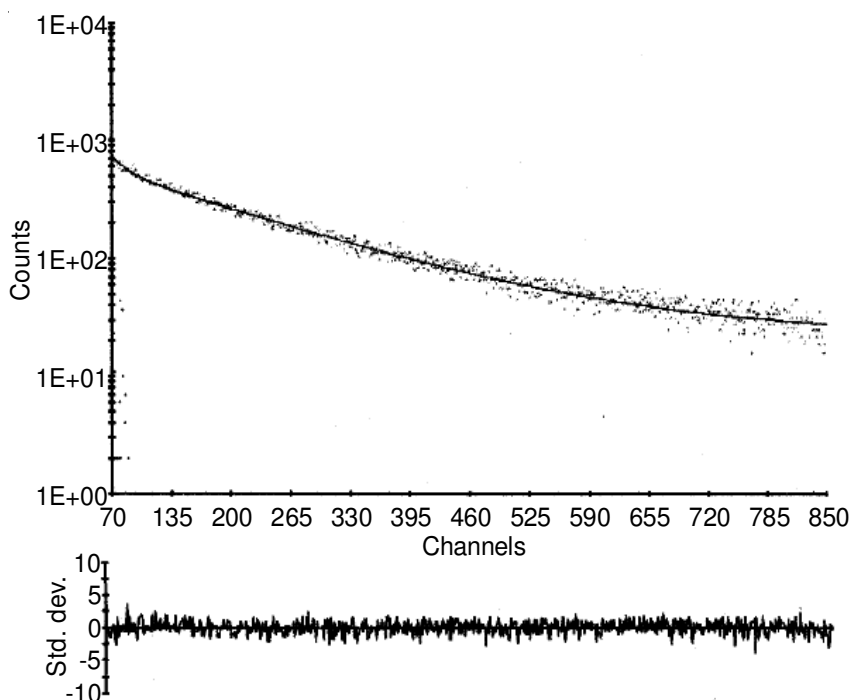

Fig. 5f. Fluorescence decay profile of $\mathbf{V}$ in dichloromethane. The solid line represents best fit to $\mathrm{I}(\mathrm{t})=\mathrm{A}_{1} \exp ^{-\mathrm{t} / \tau_{1}}+\mathrm{A}_{2} \exp ^{-\mathrm{t} / \tau_{2}}$. $\lambda_{\text {excitation }}=400 \mathrm{~nm}$ $\& \lambda_{\text {emission }}=650 \mathrm{~nm} . \tau_{1}=0.85 \mathrm{~ns}(4.87 \%) ; \tau_{2}=7.1 \mathrm{~ns}(95.1 \%)$

at $77 \mathrm{~K}$, we attribute the shorter life time to $\left[\mathrm{Ru}(\text { bipy })_{2} \mathrm{Cl}\right]^{+}$unit of $\mathbf{I V}$ and $\mathbf{V}$ and the longer life time to the porphyrin emission. Probably due to this short life time, we could not observe distinct emission at room temperature. However, we could not see any definite trend in either life times or amplitudes with solvent polarity. Thus, the decrease in life times of porphyrin group in IV and $\mathbf{V}$ may be attributed to increased non-radiative decay process due to heavy atom coordination.

Electrochemical properties: The cyclic and square wave voltammogram of the complex IV in dichloromethane is given in Fig. 6. Thus the three peaks in the potential range of 0 to $1.75 \mathrm{~V}$ are attributed to reversible $\left(\mathrm{i}_{\mathrm{c}} / \mathrm{i}_{\mathrm{a}}=0.875, \Delta \mathrm{E}=66 \mathrm{mV}\right)$ oxidation process of $\mathrm{Ru}^{2+} \rightarrow \mathrm{Ru}^{3+}$ at $0.68 \mathrm{~V}$ and two step one electron oxidation of porphyrins ring at 0.985 and $1.421 \mathrm{~V}$. Comparing the current intensity of oxidation of ruthenium centre and porphyrin centre, the former is found to be four times than the latter indicating presence of four ruthenium subunits in the complex. Further coulometry analysis at $0.71 \mathrm{~V}$
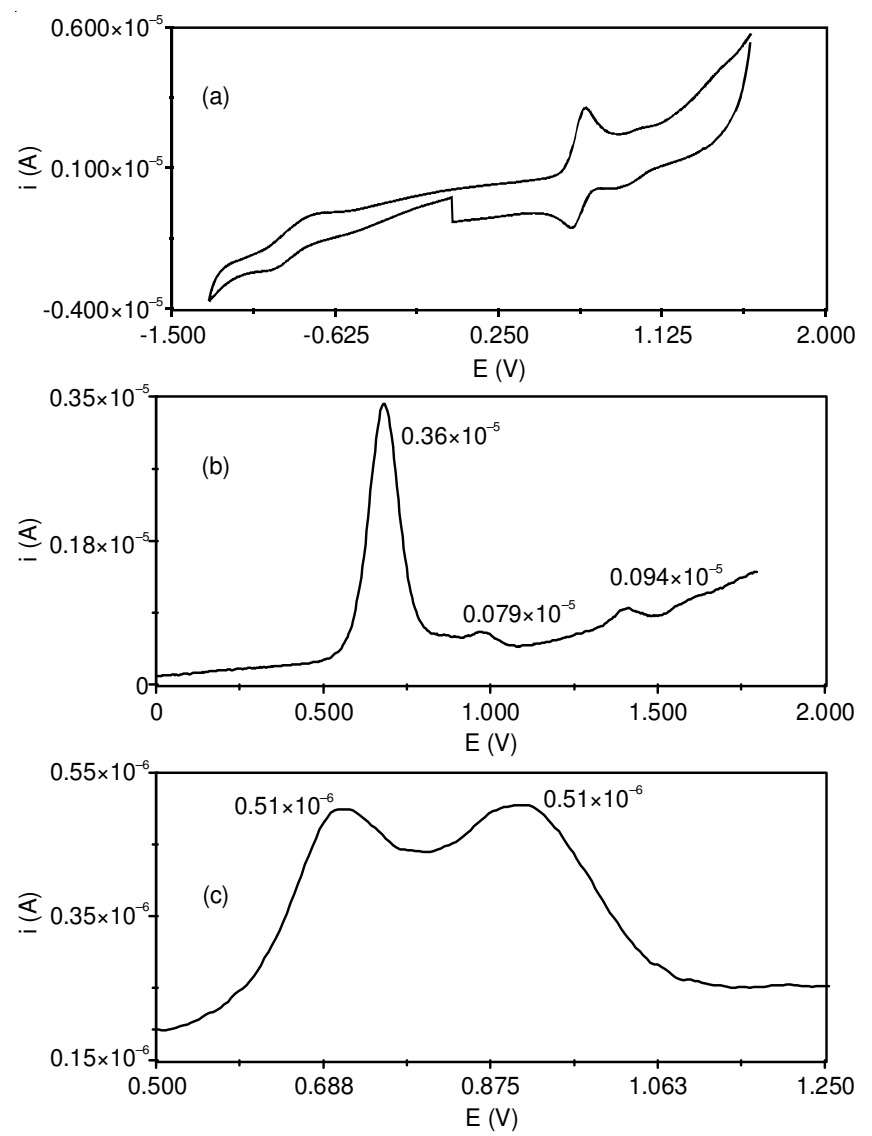

Fig. 6. (a) Cyclic voltammogram of complex IV; (b) Square wave voltammogram of IV and (c) Square wave voltammogram of $\mathbf{V}$ measured in $1 \mathrm{mM}$ TBAP in dichloromethane solution at $300 \mathrm{~K}$

confirms the transfer of four equivalents of charges in IV and one equivalent in $\mathbf{V}$.

The peak potential for the reversible oxidation process of the $\mathrm{Ru}^{3+/ 2+}$ couple in the ruthenated complexes is $0.68 \mathrm{~V}$ (vs. $\mathrm{SCE}$ ), which is more positive than the corresponding value of $0.43 \mathrm{~V}$ (vs. SCE) obtained for the unsubstituted analog cis$\mathrm{Ru}$ (bipy) ${ }_{2} \mathrm{Cl}_{2}$ [38]. This shift is taken as a bench marking for the formation of the ruthenium complex and is attributed to the increased metal to ligand charge transfer after porphyrin coordination. This is also confirmed by intentional addition of cis-[Ru(bipy $\left.)_{2} \mathrm{Cl}_{2}\right]$ to either $\mathbf{I V}$ or $\mathbf{V}$. Any unreacted cis$\left.[\mathrm{Ru} \text { (bipy })_{2} \mathrm{Cl}_{2}\right]$ would have shown oxidation at $0.43 \mathrm{~V}$ instead of $0.68 \mathrm{~V}$.

The redox potentials are tabulated in the Table-3. On comparing the oxidation potential between the complexes IV and $\mathbf{V}$, it is observed that the oxidation of ruthenium moiety is slightly difficult in $\mathbf{V}$ than in $\mathbf{I V}$. This variation arises due to difference in the number of metal coordinated to the porphyrin, which in turn affects the planarity and makes porphyrin more electron withdrawing in $\mathbf{V}$ than in IV.

Since, the cyclic voltammetric analysis gave broad peaks we studied the reduction processes taking place in the complexes through square wave voltammetry technique. The voltammetric study of the complexes in the range of 0 to $-1.75 \mathrm{~V}$ resulted in two peaks at $-0.965 \mathrm{~V}$ and $-1.530 \mathrm{~V}$, corresponding to the reduction processes taking place in the porphyrin unit and the bipyridyl unit of $\left[\mathrm{Ru}(\text { bipy })_{2} \mathrm{Cl}\right]^{+}$fragment. The coulometric analysis at $-1.58 \mathrm{~V}$ gave transfer of six equivalents of 
TABLE-3

AE POTENTIAL FROM SQUARE WAVE VOLTAMMETRIC ANALYSIS AT $300 \mathrm{~K}$, WITH SCE AS REFERENCE ELECTRODE AND TBAP AS SUPPORTING ELECTROLYTE

\begin{tabular}{|c|c|c|c|c|c|c|c|}
\hline \multirow{2}{*}{ S. No. } & \multirow{2}{*}{ Complex } & \multicolumn{3}{|c|}{ Oxidation potential (V) } & \multicolumn{3}{|c|}{ Reduction potential (V) } \\
\hline & & $\mathrm{Ru}^{2+} \rightleftharpoons \mathrm{Ru}^{2+}$ & $\mathrm{P} \rightleftharpoons \mathrm{P}^{+}$ & $\mathrm{P}^{+} \rightleftharpoons \mathrm{P}^{2+}$ & $\mathrm{P} \rightleftharpoons \mathrm{P}^{-}$ & $\mathrm{P} \rightleftharpoons \mathrm{P}^{2-}$ & bipy $\rightarrow$ bipy $^{-}$ \\
\hline 1 & $\mathbf{A}$ & - & 0.916 & 1.113 & -1.272 & -1.619 & - \\
\hline 2 & B & - & 0.972 & 1.224 & -1.266 & -1.628 & - \\
\hline 3 & $\mathbf{I}$ & - & 0.743 & 1.178 & -1.260 & -1.680 & - \\
\hline 4 & II & - & 0.789 & 1.151 & -1.258 & -1.624 & - \\
\hline 5 & III & 0.425 & - & - & - & - & -1.500 \\
\hline 6 & IV & 0.680 & 0.985 & 1.421 & -0.887 & -1.387 & -1.541 \\
\hline 7 & $\mathbf{V}$ & 0.6969 & 0.923 & - & -0.654 & -1.495 & -1.542 \\
\hline
\end{tabular}

charges. It is known that the bipyridyl of cis-[Ru(bipy $\left.)_{2} \mathrm{Cl}_{2}\right]$ reduces in the region $-1.8 \mathrm{~V}$. This mean that the higher current observed at $-1.54 \mathrm{~V}$ in the complexes arises from overlapping of bipyridyl reduction and porphyrin's second electron reduction. Thus, de-convoluted square wave voltammogram of the complex, IV (Fig. 7), shows two peaks at -1.387 and $-1.541 \mathrm{~V}$. The former corresponds to the second electron reduction of porphyrin and the latter corresponds to the reduction of the bipyridyl ligand. Furthermore, the current ratio between -1.387 and $-1.541 \mathrm{~V}$ peaks confirms coordination of four ruthenium centers in the porphyrin ring. On the other hand, the de-convoluted square wave voltammogram of the complex, $\mathbf{V}$ (Fig. 8), shows two peaks of equal intensities at $-1.495 \mathrm{~V}$ and $-1.542 \mathrm{~V}$

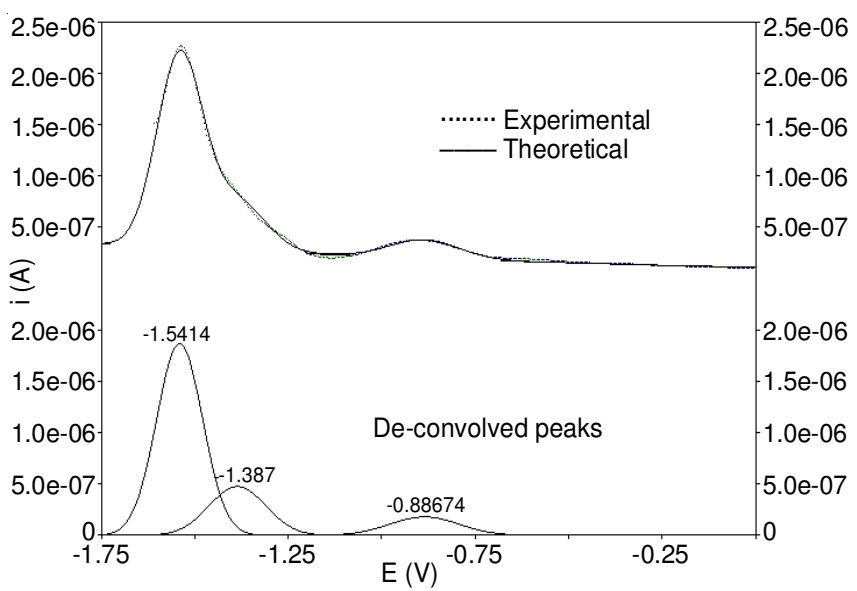

Fig. 7. Square wave voltammogram of complex IV $(0.1 \mathrm{mM})$ measured in $1 \mathrm{mM}$ TBAP in dichloromethane solution at $300 \mathrm{~K}$

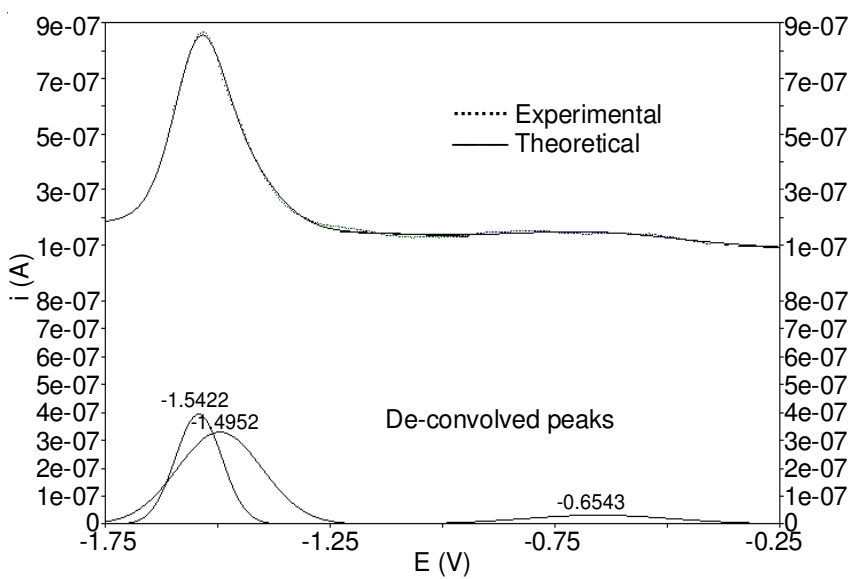

Fig. 8. Square wave voltammogram of complex $\mathbf{V}(0.1 \mathrm{mM})$ measured in $1 \mathrm{mM}$ TBAP in dichloromethane solution at $300 \mathrm{~K}$ with former corresponding to the second electron reduction of porphyrin and the latter corresponding to the reduction of the bipyridyl ligand. The difference in the intensities between the two complexes at $-1.54 \mathrm{~V}$ is an indicative of the number of bipyridyl units getting reduced or the number of ruthenium attached to the porphyrins ring.

Thus, when comparing the redox potential of porphyrin ring between the complexes and precursor, it is found that the oxidation is comparatively difficult in the complexes than in the free base porphyrin. On the other hand reduction of the porphyrin ring is easy in the complexes than in the precursor, which is an indicative of the depletion in the electron density in the porphyrin core. It is clear from the Table- 3 that the reduction potential of the complexes has shifted towards less negative potential comparing with the free base porphyrin. The electrochemical processes taking place in the complex, IV, can be summarized as:

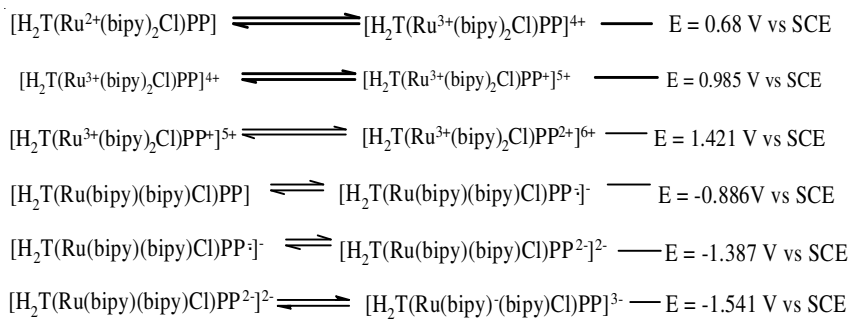

The change in the redox values must occur due to perturbations to HOMO-LUMO energies. We notice a reduction in energy of both HOMO and LUMO, with LUMO showing more stabilization. The stabilization is found to be $0.293 \mathrm{eV}$ for LUMO and $0.196 \mathrm{eV}$ for HOMO in IV and in $\mathbf{V}$ it is $0.393 \mathrm{eV}$ for LUMO and $0.134 \mathrm{eV}$ in HOMO. The larger stabilization energy of LUMO in $\mathbf{V}$ suggests that distortion is more in unsymmetrical complexes than in symmetrical. One of the reasons for this observation might be occurring due to non-planar distortion of the porphyrin ring, which probably brings the meso-phenyl group more in plane with the porphyrin ring than in the corresponding parent free base porphyrin. This in plane distortion of phenyl group would induce increased delocalization of electron towards the porphyrin ring through the phenoxo group and this is also proved by the upfield shift in the $\beta$-pyrrole hydrogens in the ${ }^{1} \mathrm{H}$ NMR spectrum. This delocalization of electron towards the porphyrin ring is also identified in an EPR study on porphyrin substituted with paramagnetic metal ion [31] at the core and at the periphery of the porphyrin ring. 


\section{Conclusion}

A new class of $\mathrm{Ru}(\mathrm{II})$ complexes of the cis- $\mathrm{Ru}$ (bipy) ${ }_{2} \mathrm{Cl}_{2}$ type with phenoxo-porphyrin ligands, $\left(\mathrm{H}_{2}(\mathrm{P})-\mathrm{Ru}_{4}\right.$ and $\mathrm{H}_{2}(\mathrm{P})$ $\mathrm{Ru})$ has been achieved. This resulted in a stable ruthenium oxygen phenolato bridged porphyrin complexes. The electronic spectra shows shift in the absorption, which is due to perturbation of the energy level. The results suggest that the ruthenium orients probably in a perpendicular to the porphyrin plane and also suggest that the meso-phenyl group might rotate into the plane of the porphyrin. At room temperature, the fluorescence of the complexes resulted in emission from porphyrin unit alone while at $77 \mathrm{~K}$ two emissions one from each chromophore is observed. This is also further confirmed by singlet life time measurement, which resulted in two life times of different amplitudes. The quantum yield measurement resulted in decreased yield than the free base porphyrin. This reduction in quantum yield can be claimed due to heavy atom effect. The electrochemical investigation of the complexes revealed the number of metal coordinated to the porphyrin, which further confirms the formation of the above said complexes. From the various analytical studies we can conclude that these complexes could act as good catalysts for many chemical transformation reactions.

\section{ACKNOWLEDGEMENTS}

The authors thanks UGC for fellowship, Dr. R. Venkatesan, for his valuable discussion of the work. The authors also thank CDRI, Lucknow, India for providing mass and elemental analysis, SIF, IISc, Bangalore, India for nuclear magnetic resonance and NCUFP, Taramani Campus, Madras University, Chennai for singlet life time measurement, DST FIST and UGC SAP.

\section{REFERENCES}

1. J.-M. Lehn, Supramolecular Chemistry: Concept and Perspectives; VCH: Weinheim, Germany (1995).

2. K.M. Kadish, K.M. Smith and R. Guilard, Biochemistry and Binding: Activation of Small Molecules, The Porphyrin Handbook, Academic Press: San Diego, CA, vol. 4 (2000).

3. K.M. Kadish, K.M. Smith and R. Guilard, Bioinorganic and Bioorganic Chemistry, The Porphyrin Handbook, The Porphyrin Handbook, Academic Press: San Diego, CA, vol. 11 (2000).

4. K.M. Kadish, K.M. Smith and R. Guilard, Applications: Past, Present and Future, The Porphyrin Handbook, Academic Press: San Diego, CA, vol. 6 (2000).

5. K.M. Kadish, K.M. Smith and R. Guilard, E. Transfer, The Porphyrin Handbook, Academic Press: San Diego, CA, vol. 8 (2000).

6. K.M. Kadish, K.M. Smith and R. Guilard, Medical Aspects of Porphyrins, The Porphyrin Handbook, Academic Press: San Diego, CA, vol. 14 (2003).

7. M.G.H. Vicente, L. Jaquinod and K.M. Smith, Chem. Commun., 1771 (1999); https://doi.org/10.1039/a902334h.

8. J. Wojaczynski and L. Latos-Grazynski, Coord. Chem. Rev., 204, 113 (2000);

https://doi.org/10.1016/S0010-8545(99)00207-6.

9. (a) H.L. Anderson, C.A. Hunter and J.K.M. Sanders, J. Chem. Soc. Chem. Commun., 226 (1989); https://doi.org/10.1039/c39890000226.

(b) I.P. Danks, T.G. Lane, I.O. Sutherland and M. Yap, Tetrahedron, 48, 7679 (1992);

https://doi.org/10.1016/S0040-4020(01)90379-5.

(c) H.L. Anderson, A. Bashall, K. Henrick, M. McPartlin and J.K.M. Sanders, Angew. Chem. Int. Ed. Engl., 33, 429 (1994);

https://doi.org/10.1002/anie.199404291.

(d) C.A. Hunter and L.D. Sarson, Angew. Chem. Int. Ed. Engl., 33, 2313 (1994);

https://doi.org/10.1002/anie.199423131.
10. C.J. Walter, H.L. Anderson and J.K.M. Sanders, J. Chem. Soc. Chem. Commun., 458 (1993); https://doi.org/10.1039/C39930000458.

11. J.R.C. da Rocha, G.J.-F. Demets, M. Bertotti, K. Araki and H.E. Toma, J. Electroanal. Chem., 526, 69 (2002); https://doi.org/10.1016/S0022-0728(02)00769-6.

12. A. Prodi, C.J. Kleverlaan, M.T. Indelli, F. Scandola, E. Alessio and E. Iengo, Inorg. Chem., 40, 3498 (2001); https://doi.org/10.1021/ic0101331.

13. E. Alessio, E. Ciani, E. Iengo, V.Y. Kukushkin and L.G. Marzilli, Inorg. Chem., 39, 1434 (2000); https://doi.org/10.1021/ic990709a.

14. H.-Z. Yu, J.S. Baskin, B. Steiger, F.C. Anson and A.H. Zewail, J. Am. Chem. Soc., 121, 484 (1999); https://doi.org/10.1021/ja983532c.

15. N. Rea, B. Loock and D. Lexa, Inorg. Chim. Acta, 312, 53 (2001); https://doi.org/10.1016/S0020-1693(00)00319-4.

16. B. Steiger and F.C. Anson, J. Porphyr. Phthalocyan., 3, 159 (1999); https://doi.org/10.1002/(SICI)1099-1409(199902)3:2<159::AIDJPP113>3.0.CO;2-E.

17. B. Steiger and F.C. Anson, Inorg. Chem., 34, 3355 (1995); https://doi.org/10.1021/ic00116a031.

18. B. Steiger and F.C. Anson, Inorg. Chem., 33, 5767 (1994); https://doi.org/10.1021/ic00103a026.

19. C.N. Shi and F.C. Anson, Electrochim. Acta, 39, 1613 (1994); https://doi.org/10.1016/0013-4686(94)85144-1.

20. J.R.C. da Rocha, L. Angnes, M. Bertotti, K. Araki and H.E. Toma, Anal. Chim. Acta, 452, 23 (2002); https://doi.org/10.1016/S0003-2670(01)01440-4.

21. H.E. Toma and K. Araki, Coord. Chem. Rev., 196, 307 (2000); https://doi.org/10.1016/S0010-8545(99)00041-7.

22. K. Araki, C.A. Silva, H.E. Toma, L.H. Catalani, M.H.G. Medeiros and P. Di Mascio, J. Inorg. Biochem., 78, 269 (2000); https://doi.org/10.1016/S0162-0134(00)00053-2.

23. M.H. Wall Jr., S. Akimoto, T. Yamazaki, N. Ohta, I. Yamazaki, T. Sakuma and H. Kido, Bull. Chem. Soc. Jpn., 72, 1475 (1999); https://doi.org/10.1246/bcsj.72.1475.

24. K. Araki and H.E. Toma, J. Photochem. Photobiol. Chem., 83, 245 (1994); https://doi.org/10.1016/1010-6030(94)03821-X.

25. D.D. Perrin and W.L.F. Armarego, Purification of Laboratory Chemicals, A. Wheaton and Co. Ltd., Great Britain, edn 3, Chap. 3 (1988).

26. A.D. Adler, F.R. Longo, J.D. Finarelli, J. Goldmacher, J. Assour and L. Korsakoff, J. Org. Chem., 32, 476 (1967); https://doi.org/10.1021/jo01288a053.

27. G. Etemad-Moghadam, L. Ding, F. Tadj and B. Meunier, Tetrahedron, 45, 2641 (1989); https://doi.org/10.1016/S0040-4020(01)80094-6.

28. A.H. Cowley, Inorganic Synthesis, John Wiley \& Sons, New York, vol. 31, p. 117 (1997).

29. B.P. Sullivan, D.J. Salmon and T.J. Meyer, Inorg. Chem., 17, 3334 (1978); https://doi.org/10.1021/ic50190a006.

30. G.A. Crosby and J.N. Demas, J. Phys. Chem., 75, 991 (1971); https://doi.org/10.1021/j100678a001.

31. D.J. Quimby and F.R. Longo, J. Am. Chem. Soc., 97, 5111 (1975); https://doi.org/10.1021/ja00851a015.

32. R.M. Silverstein, F.X. Webster and D.J. Kiemle, Spectrometric Identification of Organic Compounds, John Wiley \& Sons, Inc., edn 7 (2005).

33. H. Scheer and J.J. Katz, ed.: K.M. Smith, Porphyrin and Petalloporphyrin, Elseiver, pp 399 (1975).

34. M. Haga, E.S. Dodsworth and A.B.P. Lever, Inorg. Chem., 25, 447 (1985); https://doi.org/10.1021/ic00224a013.

35. I.P. Evans, A. Spencer and G.J. Wilkinson, J. Chem. Soc., Dalton Trans., 204 (1973); https://doi.org/10.1039/dt9730000204.

36. R. Venkatesan, Ph. D. Thesis, Indian Institute of Technology, Mumbai, India (1991).

37. K. Kalyanasundaram, Coord. Chem. Rev., 46, 159 (1982); https://doi.org/10.1016/0010-8545(82)85003-0.

38. S. Tamijselvy, Ph.D. Thesis, Pondicherry University, Pondicherry, India (2003). 